\title{
Gluconacetobacter entanii sp. nov., isolated from submerged high-acid industrial vinegar fermentations
}

\author{
Gerd Schüller, Christian Hertel and Walter P. Hammes
}

Institut für

Lebensmitteltechnologie, Universität Hohenheim, Garbenstraße 28, D-70593 Stuttgart, Germany
Author for correspondence: Christian Hertel. Tel: +49 711459 4255. Fax: +49 7114594199. e-mail: hertel@uni-hohenheim.de

Acetic acid bacteria have been isolated from submerged high-acid spirit vinegar fermentations in the Southern part of Germany. Four strains (LTH 4560', LTH 4341, LTH 4551 and LTH 4637) were characterized in more detail and it was revealed that they have in common certain properties such as requirement of acetic acid, ethanol and glucose for growth, and no overoxidation of acetate. Growth occurs only at total concentrations (sum of acetic acid and ethanol) exceeding $6.0 \%$. A method for their preservation was developed. Comparative analysis of the 165 rRNA revealed sequence similarities of $>99 \%$ between strain LTH $4560^{\top}$ and the type strains of the related species Gluconacetobacter hansenii. However, low levels of DNA relatedness $(<41 \%)$ were determined in DNA-DNA similarity studies. In addition, specific physiological characteristics permitted a clear identification of the strains within established species of acetic acid bacteria. The strains could also be differentiated on the basis of the distribution of IS element $1031 \mathrm{C}$ within the chromosome. Based on these results, the new species Gluconacetobacter entanii sp. nov. is proposed for strain LTH $4560^{\top}$ ( = DSM 13536'). A 16S-rRNA-targeted oligonucleotide probe was constructed that was specific for $G$. entanii, and the phylogenetic position of the new species was derived from a 16S-rRNA-based tree.

Keywords: Gluconacetobacter entanii sp. nov., acetic acid bacteria, spirit vinegar fermentation

\section{INTRODUCTION}

The production of high-acid vinegar has been enabled by the use of submerged fermentation processes in socalled acetators. Depending on the strain of acetic acid bacteria and the nature of the fermentation substrate, final acetic acid concentrations of up to $15-16 \%$ can be achieved. In contrast to the high standard of the fermentation technology, the microbiology of vinegar fermentation is well below the standard of that of dairy or meat fermentation, for example. When vinegar fermentations have to be started or a breakdown of a fermentation process requires the restart of an acetator, a microbiologically undefined inoculum is commonly used (Sokollek \& Hammes, 1997). The lack of defined pure starter cultures is due to problems in

The GenBank accession number for the 16S rDNA sequence of strain LTH $4560^{\top}$ is AJ251110. isolation and conservation of acetic acid bacteria involved in high-acid vinegar production (Sievers \& Teuber, 1995). After the introduction of a double-layer agar technique by Entani et al. (1985), the first isolations of acetic acid bacteria from that environment were achieved. 'Acetobacter polyoxogenes' was described as a new species; however, the strain was not deposited in a culture collection. Later on, Sievers et al. (1992) described Gluconacetobacter europaeus as the dominant species of acetic acid bacteria in industrial vinegar fermenters in central Europe. The authors reported that with the exception of the type strain of $G$. europaeus, the acetic acid bacteria isolated from highacid submerged vinegar fermentations could not be preserved. Recently, preservation methods were described to improve the handling of the acetic acid bacteria outside of the fermentation process (Sokollek et al., 1998a). In these studies, strains were isolated from running spirit vinegar fermentations which could 
not be allotted to any species of the acetic acid bacteria, thus indicating that in addition to G. europaeus other species are involved in the fermentation process. It is the purpose of this communication to describe the isolation and characterization of a new Gluconacetobacter species involved in high-acid spirit vinegar fermentations.

\section{METHODS}

Bacterial strains and growth conditions. The strains investigated were isolates from running acetators. Isolates LTH 4341 and LTH 4551 were obtained by Sokollek et al. (1998a). Strains LTH $4560^{\mathrm{T}}$ and LTH 4637 were isolated from spirit vinegar fermentations at total concentrations [i.e. percentage $(\mathrm{w} / \mathrm{v})$ acetic acid plus percentage $(\mathrm{v} / \mathrm{v})$ ethanol] of 14.6 and $13.4 \%$, respectively. The type strains of the acetic acid bacteria were obtained from the DSMZ (Deutsche Sammlung von Mikroorganismen und Zellkulturen, Braunschweig, Germany). Gluconacetobacter xylinus was grown in YPM medium containing $\left(1^{-1}\right): 5$ g yeast extract, 3 g peptone and $25 \mathrm{~g}$ mannitol. Gluconacetobacter hansenii and Gluconacetobacter oboediens [formerly Acetobacter oboediens (Yamada, 2000)] were propagated in RAE medium (1a/2e) (Sokollek \& Hammes, 1997). AE medium (4a/3e) (Sokollek \& Hammes, 1997) was used as growth medium for isolates from high-acid spirit vinegar fermentations. Shaking cultures were incubated at $30^{\circ} \mathrm{C}$ on a rotary shaker at 200 r.p.m. in 11 triple-baffled Erlenmeyer flasks containing $200 \mathrm{ml}$ medium. Surface cultures on agar plates were incubated at $30{ }^{\circ} \mathrm{C}$ at $>95 \%$ relative humidity. Viable cell counts were determined by surface plating on AE (4a/3e) broth for the serial dilutions. Total cell counts were determined with the aid of a Thoma haemocytometer.

Preservation of the strains. For preservation, $200 \mathrm{ml} \mathrm{AE}$ broth $(4 \mathrm{a} / 3 \mathrm{e})$ was inoculated with a 7-d-old colony taken from $\mathrm{AE}$ agar $(4 \mathrm{a} / 3 \mathrm{e})$ and incubated on a rotary shaker for at least $5 \mathrm{~d}$. At mid-exponential growth (at an $\mathrm{OD}_{600}$ of $0 \cdot 6-0 \cdot 7)$, the concentration of acetic acid was determined by titration with $0 \cdot 1 \mathrm{M} \mathrm{NaOH}$. For each mole of acetic acid, $0.5 \mathrm{~mol} \mathrm{CaCO}_{3}$ was added to the culture broth and the incubation was continued for $2 \mathrm{~min}$. The cells were immediately harvested by centrifugation at $3000 \mathrm{~g}$ for $4 \mathrm{~min}$ at $0{ }^{\circ} \mathrm{C}$. After resuspension in $2 \mathrm{ml}$ ice-cold $20 \%$ malt extract solution (Sokollek \& Hammes, 1997), the suspension was poured drop wise in liquid nitrogen. The frozen culture was lyophilized and stored at $-20^{\circ} \mathrm{C}$.

Physiological and biochemical characterization. Growth was investigated in $\mathrm{AE}$ broth containing ethanol and acetic acid at concentrations of $0,1,2,3,4$ and $5 \%(\mathrm{v} / \mathrm{v})$ and $0,1,2,3$, $4,5,6,7,8,9,10,11$ and $12 \%(\mathrm{w} / \mathrm{v})$, respectively. The cultures were grown under aeration at $30^{\circ} \mathrm{C}$ for $14 \mathrm{~d}$. Growth on acetate at $\mathrm{pH} 2 \cdot 5$, utilization of lactate, and growth in the presence of $30 \%$ glucose were studied in bouillon as described by Sievers et al. (1992). The utilization of carbon sources was investigated in AE broth (4a/3e) by replacing glucose, ethanol or acetic acid with the substrates presented in Results. The substrates were added at a concentration of $20 \mathrm{~g} \mathrm{l}^{-1}$ or $20 \mathrm{ml} \mathrm{1}^{-1}$, respectively. Overoxidation and formation of 2- and 5-ketogluconic acid as well as gluconic acid were investigated in AE broth $(4 \mathrm{a} / 3 \mathrm{e})$ containing $2 \%$ glucose at $30^{\circ} \mathrm{C}$. After 2,7 and $14 \mathrm{~d}$ incubation, concentrations of 2- and 5-ketogluconic acid, glucose, gluconic acid and acetic acid were determined by HPLC as described by Stolz et al. (1993) with the following modifications. An Aminex cartridge cation $\mathrm{H}^{+}$and a HPX87-H (Bio-Rad) were applied as pre-column and column, respectively. The mobile phase consisted of $\mathrm{H}_{2} \mathrm{SO}_{4}(0 \cdot 05 \mathrm{M})$ and the flow rate was adjusted to $0.6 \mathrm{ml} \mathrm{m^{-1 }}$ at $60^{\circ} \mathrm{C}$. Formation of cellulose was studied in AE broth $(4 \mathrm{a} / 3 \mathrm{e})$ at $30{ }^{\circ} \mathrm{C}$. Quinones were determined as described previously (Sokollek et al., 1998b).

Fermentation in a pilot acetator. The growth of the isolates was studied in a pilot acetator (Frings) as described previously (Sokollek \& Hammes, 1997) with the following modification: the mash consisted of ethanol, acetic acid, tap water and $1.5 \mathrm{~g}$ nutrient concentrate Acetozym DS (Frings) $1^{-1}$. The total concentration was adjusted to $13 \cdot 4 \%$ for strain LTH 4637 or $14.6 \%$ for LTH $4560^{\mathrm{T}}$.

DNA isolation. Chromosomal DNA was prepared according to the CTAB method as described by Ausubel (1994). Plasmid DNA was isolated with the aid of Nucleobond AX PC 200 (Macherey-Nagel) and Qiagen-tip 100 columns.

Hybridization techniques. For hybridization with oligonucleotide probes, $5 \mu \mathrm{g}$ chromosomal DNA was denatured in $0 \cdot 2 \mathrm{M} \mathrm{NaOH} / 2 \times \mathrm{SSC}$ at $37^{\circ} \mathrm{C}$ for $20 \mathrm{~min}$ and transferred to a nylon membrane (Qiabrane; Qiagen) using a dot blot apparatus (Schleicher \& Schuell). Oligonucleotides were labelled with the $3^{\prime}$ digoxigenin oligo-labelling kit (Boehringer Mannheim). Hybridizations were carried out as recommended by the supplier. Stringent washing was performed twice in $2 \times \mathrm{SSC} / 0 \cdot 1 \% \mathrm{SDS}$ for $10 \mathrm{~min}$ at probespecific temperatures. The accessibility of immobilized DNA was determined by hybridization with the 16S rDNA bacterial probe EUB 338 (Amann et al., 1990). The probespecific hybridization and stringent washing temperatures were 44 and $48^{\circ} \mathrm{C}$, respectively. Detection of hybrids was performed by using a DIG luminescent detection kit (Boehringer Mannheim).

For Southern hybridization, $2 \mu \mathrm{g}$ chromosomal DNA was digested with HindIII and subjected to agarose gel electrophoresis. Blotting was performed on nylon membranes (Quiabrane; Qiagen) with the aid of Vaku-Blot Apparatus (Pharmacia). An 888 bp fragment of IS 1031C was labelled with DIG-dUTP by using a PCR DIG probe synthesis kit (Boehringer Mannheim), plasmid pDCB29 (Coucheron, 1993) as the template and primers IS1031AF (5'-TTTGAACAATACCAGCMTG-3') and IS1031BR (5'-SMYTGACAATGCCTTGC-3'). Hybridization was performed at $69{ }^{\circ} \mathrm{C}$ as recommended by the supplier. The membranes were washed three times for $20 \mathrm{~min}$ in $2 \times \mathrm{SSC} / 0 \cdot 1 \% \mathrm{SDS}$ at $70{ }^{\circ} \mathrm{C}$. Hybrids were detected with the aid of a DIG luminescent detection kit (Boehringer Mannheim).

For determination of DNA similarities, the hybridization was performed as described previously (Sokollek et al., 1998b).

Sequencing and analysis of 16S rDNA. Amplification and sequencing of $16 \mathrm{~S}$ rDNA were performed as described previously (Probst et al., 1998). The sequence data were added to alignments of deposited complete primary structures of $16 \mathrm{~S}$ rRNA. The phylogenetic relationship was determined by applying maximum-parsimony and maximum-likelihood approaches on data sets varying with respect to the selection of reference sequences as well as sequence positions. The respective tools of the ARB program package (Springer et al., 1992) were used for alignment, selection of positions according to variability, calculation of similarities as well as tree reconstruction, evaluation and drawing. 
DNA base composition. The DNA $\mathrm{G}+\mathrm{C}$ content was determined by direct analysis of the nucleosides by HPLC according to the method of Mesbah et al. (1989). All enzymes for nucleoside preparations were purchased from Boehringer Mannheim. Non-methylated lambda DNA (Sigma) was used as the standard.

\section{RESULTS}

\section{Isolation of Gluconacetobacter strains}

Strains were isolated from running industrial spiritvinegar fermentations in Southern Germany. The technique described by Entani et al. (1985) was employed. Small, round and light-grey to light-brownish colonies were obtained on $\mathrm{AE}$ agar $(4 \mathrm{a} / 3 \mathrm{e})$ within 5-10 d upon incubation at $30^{\circ} \mathrm{C}$ in an atmosphere of $>95 \%$ relative humidity. Each fermenter contained one predominant strain, as revealed by comparison of the plasmid profiles and IS element fingerprints. The strains could not be allotted to the type strains of acetic acid bacteria applying 16S-rRNA-targeted probes (Sokollek et al., 1998a).

\section{Morphological and cultural characteristics}

Microscopically, the cells appeared as non-motile, and non-flagellated rods, preferentially occurring in pairs.
In $\mathrm{AE}$ broth, the strains grew at temperatures ranging from 20 to $34{ }^{\circ} \mathrm{C}$, with an optimum of $30^{\circ} \mathrm{C}$, and at $\mathrm{pH}$ values ranging between $2 \cdot 2$ and $3 \cdot 0$, with an optimum of $\mathrm{pH} 2 \cdot 7$. In this medium, the total concentration (acetic acid plus ethanol) was kept $>6.0$ with a minimum of $4 \%$ acetic acid and a maximum of $4 \%$ ethanol. In addition, the strains could be cultivated in yeast nitrogen base (Difco) supplemented with $0.5 \%$ glucose, $3 \%$ ethanol and $4 \%$ acetic acid.

\section{Genotypic differentiation of the strains}

Plasmids were isolated from the strains and subjected to gel electrophoresis. Identical plasmid profiles were found for isolates LTH 4341, LTH 4551 and LTH 4637. A slightly different profile was obtained for strain LTH $4560^{\mathrm{T}}$ (Fig. 1a). The plasmid profiles were compared with those obtained from the cultures in the acetators used as the source of the isolates. Identical profiles indicated that the predominant strain of the spirit vinegar acetators had been isolated. Genomic DNA of the strains was hybridized with a polynucleotide probe specific for the IS element $1031 \mathrm{C}$ occurring in the genome of G. xylinus (Coucheron, 1993). As shown in Fig. 1(b), closely related IS profiles were obtained. These permitted unambiguous differentiation of the four strains.
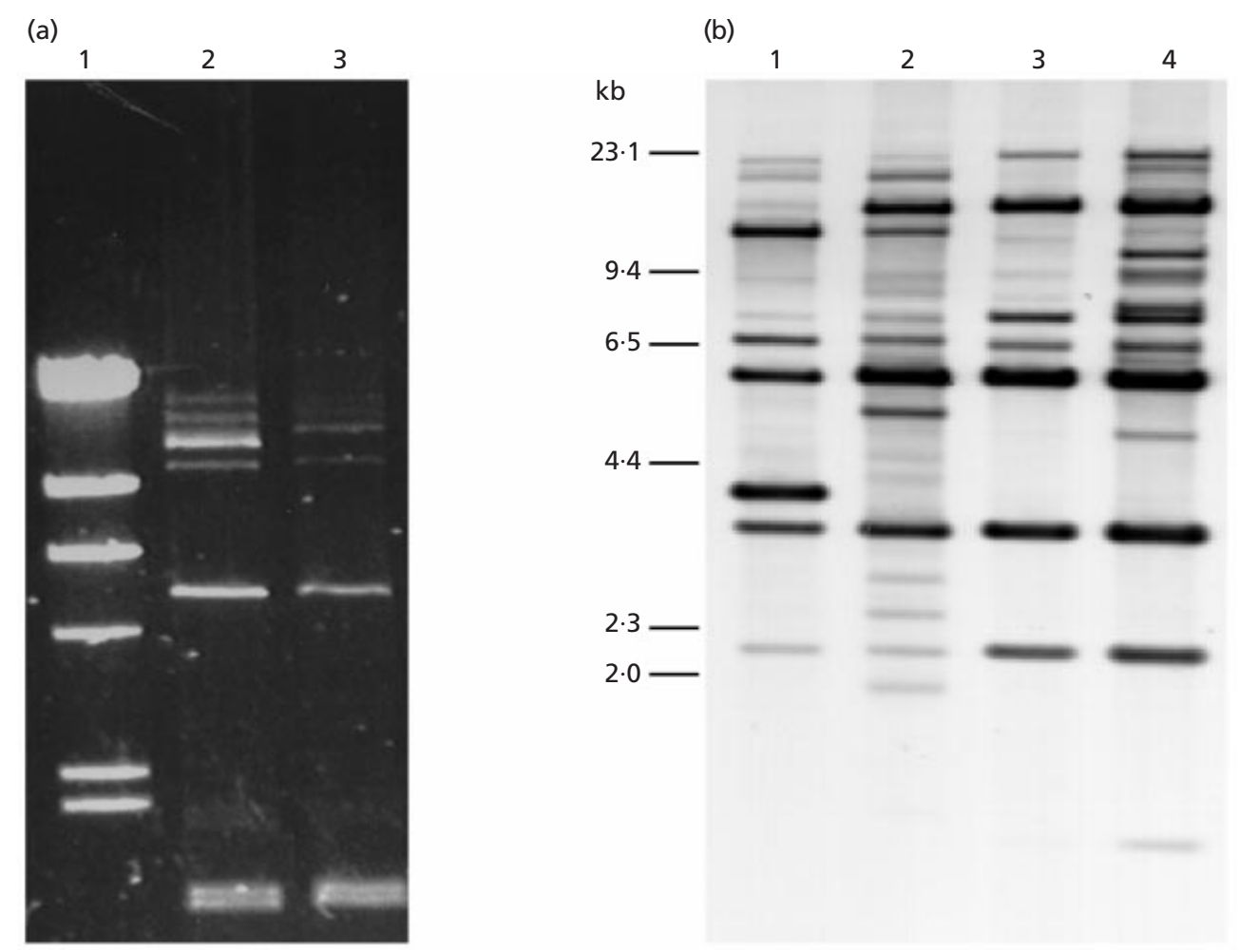

Fig. 1. (a) Electrophoretic patterns of plasmid DNAs isolated from two $G$. entanii strains. Lanes: 1 , lambda DNA/HindIII marker; 2, LTH $4560^{\top}$; 3, LTH 4637. (b) Distribution of IS $1031 \mathrm{C}$ in the genomes of four $G$. entanii strains. Total DNA was

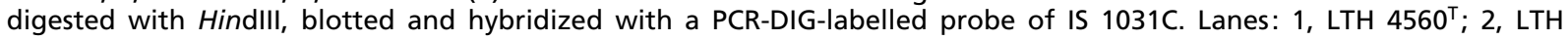
4637; 3, LTH 4341; 4, LTH 4551. 


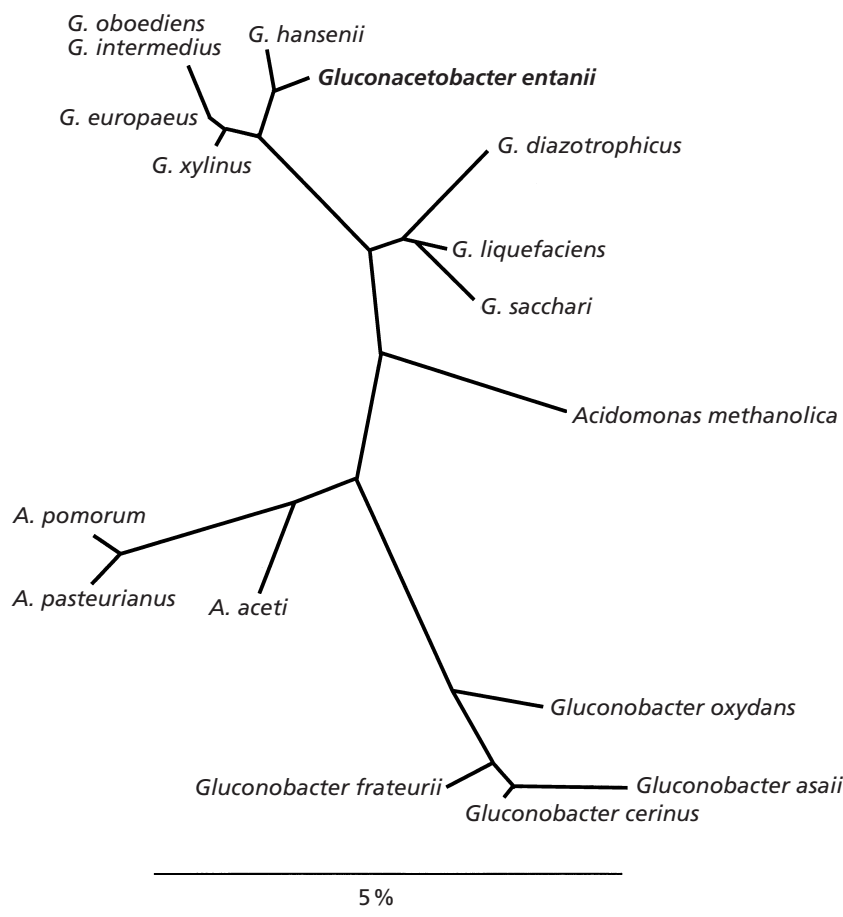

Fig. 2. 16S-rRNA-based tree reflecting the phylogenetic position of $G$. entanii ( $\left(\mathrm{THH} 4560^{\top}\right.$ ) within the acetic acid bacteria. A tree was constructed which is based on a maximumlikelihood tree and a data set containing all available almost complete 16S rRNA sequences from acetic acid bacteria and selected reference organisms from the $\alpha$-subclass of Proteobacteria. All positions were used for the calculation. The tree topology was corrected according to the results of distance matrix and maximum-parsimony analysis. The bar indicates $5 \%$ estimated sequence divergence. The GenBank accession numbers for the $16 \mathrm{~S}$ rRNA sequences of strains of acetic acid bacteria are: Acetobacter aceti JCM 7641, D30768; Acetobacter pasteurianus LMD 22.1, X71863; Acetobacter pomorum DSM 11825, AJ001632; Acidomonas methanolica DSM 5432, X77468; Gluconacetobacter diazotrophicus DSM 5601, X75618; Gluconacetobacter europaeus DSM 6160, Z21936; Gluconacetobacter hansenii NCIB 8746, X75620; Gluconacetobacter intermedius [formerly Acetobacter intermedius (Yamada, 2000)] DSM 11804, Y14694; Gluconacetobacter liquefaciens IFO 12388, X75617; G. oboediens DSM 11826, AJ001631; Gluconacetobacter sacchari DSM 12717, AF127407; Gluconacetobacter xylinus NCIB 11664, X75619; Gluconobacter asaii IFO 3276, X80165; Gluconobacter frateurii IFO 3264, X82290; Gluconobacter oxydans DSM 3503, X73820.

\section{S rDNA sequence analysis and probe construction}

The sequence of the 16S rDNA of strain LTH $4560^{\mathrm{T}}$ was determined and analysed by comparison with the 16S rRNA sequences of the type strains of acetic acid bacteria (Sievers et al., 1994a, b, 1995; Sokollek et al., 1998b; Boesch et al., 1998; Franke et al., 1999). A similarity of $>99 \%$ was found between the sequence of strain LTH $4560^{\mathrm{T}}$ and that of $G$. hansenii. Two single nucleotide deletions as well as 15 base changes were detected. Based on these sequence data, the phylogenetic tree depicted in Fig. 2 was constructed reflecting the position of the strains within the genera Acetobacter, Acidomonas, Gluconacetobacter and Glu- conobacter. The results of the $16 \mathrm{~S}$ rDNA sequence comparison permitted the construction of the oligonucleotide probe AI4560 (5'-GAAACCGAGGCTAATAC-3') which is specific for strain LTH $4560^{\mathrm{T}}$. The specificity of the probe was evaluated by dot blot hybridization to genomic DNA, including that of strains LTH 4341, LTH 4551 and LTH 4637 and the closely related type strains of the Acetobacteraceae. For hybridization and stringent washing, the probespecific temperatures were defined as 48 and $50{ }^{\circ} \mathrm{C}$, respectively. Probe AI4560 reacted exclusively with DNA of the four isolates.

\section{DNA similarity}

Quantitative DNA-DNA reassociation studies were performed with the chromosomal DNA of strains LTH $4560^{\mathrm{T}}$, LTH 4341, LTH 4551, LTH 4637, $G$. europaeus DSM $6160^{\mathrm{T}}$, G. xylinus DSM 6513 ${ }^{\mathrm{T}}$, G. oboediens DSM $11826^{\mathrm{T}}$ and $G$. hansenii DSM $5602^{\mathrm{T}}$. These species were chosen on the basis of their close relatedness, which is reflected by the cluster formation as shown in Fig. 2. Hybridizations were performed using the labelled DNA of G. europaeus DSM $6160^{\mathrm{T}}$, G. xylinus DSM 6513 ${ }^{\mathrm{T}}$, G. hansenii DSM $5602^{\mathrm{T}}$ and strain LTH $4560^{\mathrm{T}}$ as probes. As shown in Table 1, the isolates exhibited levels of DNA relatedness with the type strains below $41 \%$. The relatedness of the isolates among each other was $\geqslant 89 \%$.

\section{Physiological and biochemical characterization}

The taxonomically relevant physiological properties were investigated for strains LTH $4560^{\mathrm{T}}$ and LTH 4637. As the two strains exhibited the same physiological properties, the results obtained for strain LTH $4560^{\mathrm{T}}$ were compared with the characteristics of the type strains of the acetic acid bacteria (Table 1). Remarkably, the isolates did not grow in AE broth without acetic acid. Within the genus Gluconacetobacter, this property has been described only for $G$. europaeus and the unvalidated species ' $A$. polyoxogenes'. On the other hand, strain LTH $4560^{\mathrm{T}}$ can be distinguished from the type strain of $G$. europaeus by the inability to grow on acetate at any $\mathrm{pH}$ and on lactate. Furthermore, ubiquinones Q-10 and Q-9 were found to be the major and minor component of the ubiquinone system, respectively. The DNA $\mathrm{G}+\mathrm{C}$ content of strain LTH $4560^{\mathrm{T}}$ was determined to be $58 \mathrm{~mol} \%$.

For further physiological characterization of isolates LTH $4560^{\mathrm{T}}$ and LTH 4637, the utilization of various carbon sources was studied in comparison with the type strains of G. europaeus and G. hansenii. AE broth was used as basic medium, and acetic acid, ethanol or glucose was exchanged as indicated in Table 2. The two isolates exhibited similar properties with regard to their capacity to utilize the various substrates. Strain LTH 4637 could only be distinguished from LTH $4560^{\mathrm{T}}$ by its ability to utilize sorbitol and mannitol. None of the cultures grew on methanol, n-butanol or 
Table 1. Characteristics of strain LTH $4560^{\top}$ permitting its differentiation from other species of the genera Acetobacter, Acidomonas and Gluconacetobacter

+ , Positive; d, some strains positive; $(+)$, weak positive reaction; -, negative; ND, not determined. 1, Gluconacetobacter liquefaciens; 2, Gluconacetobacter diazotrophicus; 3, G. oboediens; 4, G. xylinus; 5, G. europaeus; 6, LTH 4560" ; 7, G. hansenii; 8, Acidomonas methanolica; 9, Acetobacter pasteurianus; 10, Acetobacter pomorum; 11, Acetobacter aceti.

\begin{tabular}{|c|c|c|c|c|c|c|c|c|c|c|c|}
\hline Characteristic & 1 & 2 & 3 & 4 & 5 & $6^{*}$ & 7 & 8 & 9 & 10 & 11 \\
\hline $\begin{array}{l}\text { Growth on } 3 \%(\mathrm{v} / \mathrm{v}) \text { ethanol in the } \\
\text { presence of } 4-8 \%(\mathrm{w} / \mathrm{v}) \text { acetic acid }\end{array}$ & - & - & + & - & + & + & - & - & - & - & - \\
\hline Growth without acetic acid & + & + & + & + & - & - & + & + & + & + & + \\
\hline Growth on acetate at $\mathrm{pH} 2 \cdot 5$ & - & ND & + & - & + & - & + & - & - & - & - \\
\hline \multicolumn{12}{|l|}{ DNA-DNA homology with:* } \\
\hline LTH $4560^{\mathrm{T}}$ & ND & ND & 26 & 18 & 32 & 100 & 39 & ND & ND & ND & ND \\
\hline G. xylinus & ND & ND & 32 & 100 & 39 & 18 & 14 & ND & ND & ND & ND \\
\hline G. hansenii & ND & ND & 16 & 14 & 17 & 41 & 100 & ND & ND & ND & ND \\
\hline G. europaeus & ND & ND & 41 & 36 & 100 & 28 & 11 & $\mathrm{ND}$ & ND & ND & ND \\
\hline \multicolumn{12}{|c|}{ Formation of ketogluconic acids from D-glucose } \\
\hline 2-Ketogluconic acid & $\mathrm{d}$ & + & + & + & $\mathrm{d}$ & - & $\mathrm{d}$ & - & $\mathrm{d}$ & - & + \\
\hline 5-Ketogluconic acid & $\mathrm{d}$ & - & - & + & $\mathrm{d}$ & - & $\mathrm{d}$ & - & - & - & + \\
\hline \multicolumn{12}{|l|}{ Growth in the presence of: } \\
\hline Ethanol & + & + & + & - & + & + & + & $(+)$ & $\mathrm{d}$ & + & + \\
\hline Lactate & + & $(+)$ & + & + & $\mathrm{d}$ & - & + & - & $\mathrm{d}$ & + & + \\
\hline $30 \%(w / v)$ D-glucose & - & + & + & - & - & - & - & - & - & + & - \\
\hline DNA G $+\mathrm{C}$ content $(\mathrm{mol} \%)$ & $62-65$ & $61-63$ & $59 \cdot 9$ & $55-63$ & $56-58$ & 58 & $58-63$ & 62 & 53-63 & $50 \cdot 5$ & $56-60$ \\
\hline
\end{tabular}

* Data obtained in this work; all other data were taken from Sievers et al. (1992) and Sokollek et al. (1998b).

Table 2. Utilization of carbon sources in $A E(4 a / 3 e)$ broth

-, No growth; w, reduced growth; +, good growth.

\begin{tabular}{|c|c|c|c|c|}
\hline Carbon source & G. europaeus & G. hansenii & LTH $4560^{\mathrm{T}}$ & LTH 4637 \\
\hline $\mathrm{AE}(4 \mathrm{a} / 3 \mathrm{e})$ broth & + & $\mathrm{w}$ & + & + \\
\hline Without glucose & + & - & - & - \\
\hline \multicolumn{5}{|l|}{ AE (4a) broth } \\
\hline Without ethanol & + & - & - & - \\
\hline With n-propanol & + & - & + & + \\
\hline \multicolumn{5}{|c|}{ AE $(4 a / 3 e)$ broth - glucose replaced by: } \\
\hline Fructose & + & - & + & + \\
\hline Maltose & + & $\mathrm{w}$ & + & + \\
\hline Sucrose & + & - & + & + \\
\hline Glycerol & + & - & - & - \\
\hline Sorbitol & + & - & $\mathrm{w}$ & + \\
\hline Mannitol & + & - & - & $\mathrm{w}$ \\
\hline Gluconate & + & - & - & - \\
\hline Lactate & + & - & - & - \\
\hline AE (3e) broth without acetic acid & - & + & - & - \\
\hline \multicolumn{5}{|c|}{$\mathrm{AE}(3 \mathrm{e})$ broth - acetic acid replaced by: } \\
\hline Lactate & + & - & - & - \\
\hline Gluconate & - & + & - & - \\
\hline
\end{tabular}

D-ribose. Finally, no over-oxidation of acetic acid was observed for strains LTH $4560^{\mathrm{T}}$ and LTH 4637 in AE broth $(4 \mathrm{a} / 3 \mathrm{e})$ containing $2 \%$ glucose. Under these conditions, the glucose was not metabolized and no gluconic acid was formed, and no growth was observed in $\mathrm{AE}$ broth $(4 \mathrm{a} / 3 \mathrm{e})$ without glucose. 


\section{Performance of the isolates in pilot acetic acid fermentation}

In pilot acetic acid fermentations, the strains proved highly adapted to the semi-continuous fermentation conditions and achieved productivities $(\eta)$ (Sokollek \& Hammes, 1997) of $>6$ at total concentrations ranging between 7 and $11.0 \%$. However, the strains isolated from four independently running spirit vinegar fermenters in Southern Germany showed different degrees of productivity $(\eta)$ at high total concentrations of ethanol and acetic acid, and differed in their tolerance to high total concentrations. Strains LTH $4560^{\mathrm{T}}$, LTH 4551, LTH 4341 and LTH 4637 achieved productivities of $4-4.5 \%$ acetic acid per $24 \mathrm{~h}$ at total concentrations of $14.6,14.4,14.4$ and $13.4 \%$, respectively. The fermentation characteristics (productivity and tolerance to high total concentration) were found to be identical to those of the industrial fermentations from which the strains were isolated.

\section{Preservation of isolates from high-acid submerged fermentation}

It was observed that the total counts in the fermenting spirit vinegar mash at total concentrations ranging between 7 and $14.5 \%$ did not exceed $2-4 \times 10^{8}$ cells $\mathrm{ml}^{-1}$. However, the determination of the viable counts by surface plating on $\mathrm{AE}(4 \mathrm{a} / 3 \mathrm{e})$ agar yielded only $<1 \times 10^{4}$ c.f.u. $\mathrm{ml}^{-1}$. After the addition of $\mathrm{CaCO}_{3}$ to the culture broth at primary isolation from the mash (total concentration $13.2 \%$ ), viable counts of $5 \times 10^{6}$ c.f.u. $\mathrm{ml}^{-1}$ were achieved, for example with strain LTH $4560^{\mathrm{T}}$. The protective effect of $\mathrm{CaCO}_{3}$ at primary isolation is even stronger when the mash has a reduced total concentration. For example, the total cell count of an acetator culture of strain LTH $4560^{\mathrm{T}}$ running at a total concentration of $7.6 \%$ was $2.4 \times 10^{8}$ c.f.u. $\mathrm{ml}^{-1}$ and the viable count was $2 \cdot 7 \times 10^{7}$ c.f.u. $\mathrm{ml}^{-1}$ (survival $22 \cdot 5 \%$ ). The strains were finally subjected to lyophilization as described by Sokollek \& Hammes (1997) and were found to be viable upon storage for 2 months at $-18{ }^{\circ} \mathrm{C}$.

\section{DISCUSSION}

Based on the culture techniques for acetic acid bacteria described by Entani et al. (1985), it was possible to study in more detail the fermentation flora involved in high-acid spirit vinegar fermentations. With these techniques, Entani et al. (1985) characterized an organism ('Acetobacter polyoxogenes') involved in submerged vinegar fermentations in Japan. In our investigations, a homogeneity in the fermentation flora became apparent in fermenters run with spirit alcohol. The isolates were characterized on the genomic and physiological level and it was observed that they have defined properties in common: (i) growth occurs only in the presence of acetic acid, ethanol and glucose; (ii) growth occurs only at total concentrations (sum of acetic acid and ethanol) exceeding $6.0 \%$; (iii) the strains do not over-oxidize acetic acid. These char- acteristics reveal a striking similarity between the properties of the isolates and those described for ' $A$. polyoxogenes' (Entani et al., 1985). Sievers et al. (1992) isolated a further species from high-acid fermentation, G. europaeus. This organism can be differentiated from our isolates, which do not grow on acetic acid at $\mathrm{pH} 2.5$ and do not utilize glycerol, gluconate or lactate. Furthermore, G. europaeus can over-oxidize acetic acid and grows at total concentrations below $6 \%$ (Sokollek et al., 1998a).

The study of the $16 \mathrm{~S}$ rRNA revealed a sequence similarity of $>99 \%$ between strain LTH $4560^{\mathrm{T}}$ and $G$. hansenii. This level of phylogenetic relatedness, derived from the comparative rRNA sequence analysis, can only provide differentiating information and is not sufficient to be used for the definition of a species. On the other hand, the superior method for phylogenetic investigations at and below the species level is the quantitative hybridization analysis of genomic DNA (Stackebrand \& Goebel, 1994). The DNA-DNA hybridization data clearly indicated that the isolates are new species in the family Acetobacteraceae. The relatedness was $28 \%$ between strain LTH $4560^{\mathrm{T}}$ and G. europaeus, and $41 \%$ between strain LTH $4560^{\mathrm{T}}$ and G. hansenii. The strains had a DNA homology of $>89 \%$ among themselves. From the 16S-rRNAbased tree of relatedness of acetic acid bacteria (Fig. 2) it is evident that the isolates cluster in the $G$. xylinus/hansenii group. The use of the genus description Gluconacetobacter instead of Acetobacter is consistent with the validated proposal of Yamada et al. (1997, 1998). The detected sequence differences permitted the construction of a specific probe to clearly identify Gluconacetobacter entanii. The data obtained reveal that the strains belong to a new species. We propose the name Gluconacetobacter entanii, with strain LTH $4560^{\mathrm{T}}$ as the type strain.

The four isolates exhibit a very high degree of similarity; for example, the strains revealed identical plasmid profiles and even the profile of strain LTH $4560^{\mathrm{T}}$ shows only a slight modification in this property. A clear differentiation of the strains is possible when the distribution patterns of insertion element 1031C (Coucheron, 1993) are taken into consideration. These fingerprints are closely related but are sufficiently different to permit a strain identification. These findings can be explained on the basis of the practice of the production of high-acid vinegars in acetators. The primary inocula may be obtained from one supplier, and it is a common practice that the producers support each other by making available inocula from running acetators. Therefore, it appears likely that one competitive strain of this species (G. entanii) had developed which may have changed its pattern of IS elements during continuous propagation in a defined factory. Depending on the specific conditions employed in different factories, adaptation takes place by random mutation and selection, which is enhanced by the high content of IS elements. This conclusion is supported by the observation that the various strains exhibited 
different fermentation characteristics with regard to productivity at high total concentrations in pilot fermentation processes.

As shown by Sokollek \& Hammes (1997), the recovery of viable cells in frozen or lyophilized preparations depends on various factors. An interruption of aeration during a fermentation at high total concentrations leads immediately to a breakdown of the culture (Muraoka et al., 1982). An increase of acetic acid concentration of cultures at cell harvest poses a stress on the cells and affects the survival of the bacteria during preservation. The addition of $\mathrm{CaCO}_{3}$ to the culture broth at the time of cell harvest reduces the amount of non-dissociated acetic acid and thus increases the rates of surviving cells.

\section{Description of Gluconacetobacter entanii sp. nov.}

Gluconacetobacter entanii (en.ta'.ni.i. L. gen. entanii of Entani, in honour of Etsuzo Entani, a Japanese microbiologist who performed the crucial experiments on isolation and propagation of spirit vinegar bacteria).

Cells are Gram-negative, ellipsoidal to rod-shaped, straight or slightly curved, $0.8-1 \cdot 2 \mu \mathrm{m}$ by $1.3-1 \cdot 6 \mu \mathrm{m}$, non-motile, occurring singly, in chains and mainly in pairs. Endospores are not formed. Metabolism is respiratory, never fermentative. Colonies are round, regular, umbonate, soft, glossy and with a diameter of 1-2 mm on AE agar; catalase-positive, oxidase-negative. Growth only in the presence of acetic acid, ethanol and glucose; the total concentration (sum of acetic acid and ethanol) has to exceed $6.0 \%$. Oxidizes ethanol to acetic acid and does not over-oxidize acetic acid. Growth on $3 \%(\mathrm{v} / \mathrm{v})$ ethanol in the presence of up to $11 \%$ acetic acid (v/v). Gluconate, glycerol and lactate are not assimilated. No formation of ketogluconic acids from glucose. Good growth on glucose, fructose and sucrose in AE broth (4a/3e). Cellulose formation was not detected on solid media or in bouillon. The type strain is Gluconacetobacter entanii LTH $4560^{\mathrm{T}}(=$ DSM $13536^{\mathrm{T}}$ ), which has a DNA G $+\mathrm{C}$ content of $58 \mathrm{~mol} \%$ and has been isolated from a submerged spirit vinegar fermentation in a factory in the Southern part of Germany.

\section{ACKNOWLEDGEMENTS}

We thank S. Herr and A. Koza for excellent technical assistance and B. J. Tindall (DSMZ, Braunschweig, Germany) for helpful discussions and suggestions. We are indebted to D. H. Coucheron and T.-G. Iversen (University of Trondheim, Trondheim, Norway) for providing plasmid pDCB29. This work was supported by the FEI (Forschungskreis der Ernährungsindustrie e.V., Bonn), the AiF and the Ministry of Economics (Project no. 10610N).

\section{REFERENCES}

Amann, R. I., Binder, B. J., Olson, R. J., Chisholm, S. W., Devereux, R. \& Stahl, D. A. (1990). Combination of $16 \mathrm{~S}$ rRNA-targeted oligonucleotide probes with flow cytometry for analysing mixed microbial populations. Appl Environ Microbiol 56, 1919-1925.
Ausubel, F. M. (1994). Basic protocol: miniprep of bacterial genomic DNA. In Current Protocols in Molecular Biology. pp. 2.4.1-2.4.2. Edited by F. M. Ausubel, R. Brent, R. E. Kingston, D. D. Moore, J. G. Seidman, J. A. Smith \& K. Struhl. New York: Wiley.

Boesch, C., Trcek, J., Sievers, M. \& Teuber, M. (1998). Acetobacter intermedius sp. nov. Syst Appl Microbiol 21, 220-229.

Coucheron, D. H. (1993). A family of IS 1031 elements in the genome of Acetobacter xylinum: nucleotide sequences and strain distribution. Mol Microbiol 9, 211-218.

Entani, E., Ohmori, S., Masai, H. \& Suzuki, K.-I. (1985). Acetobacter polyoxogenes sp. nov., a new species of an acetic acid bacterium useful for producing vinegar with high acidity. J Gen Appl Microbiol 31, 475-490.

Franke, I. H., Fegan, M., Hayward, C., Leonard, G., Stackebrandt, E. \& Sly, L. I. (1999). Description of Gluconacetobacter sacchari sp. nov., a new species of acetic acid bacterium isolated from the leaf sheath of sugar cane and from the pink sugar-cane mealy bug. Int J Syst Bacteriol 49, 1681-1693.

Mesbah, M., Premachandran, U. \& Whitman, W. B. (1989). Precise measurement of the $\mathrm{G}+\mathrm{C}$ content of deoxyribonucleic acid by high-performance liquid chromatography. Int $J$ Syst Bacteriol 39, 159-167.

Muraoka, H., Watabe, Y. \& Ogasawara, N. (1982). Effect of oxygen deficiency on acid production and morphology of bacterial cells in submerged acetic fermentation by Acetobacter aceti. J Ferment Technol 60, 171-180.

Probst, A. J., Hertel, C., Richter, L., Wassill, L., Ludwig, W. \& Hammes, W. P. (1998). Staphylococcus condimenti sp. nov., from soy sauce mash, and Staphylococcus carnosus (Schleifer and Fischer 1982) subsp. utilis subsp. nov. Int J Syst Bacteriol 48, 651-658.

Sievers, M. \& Teuber, M. (1995). The microbiology and taxonomy of Acetobacter europaeus in commercial vinegar production. J Appl Bacteriol 79, S84-S95.

Sievers, M., Sellmer, S. \& Teuber, M. (1992). Acetobacter europaeus sp. nov., a main component of industrial vinegar fermenters in Central Europe. Syst Appl Microbiol 15, 386-392.

Sievers, M., Ludwig, W. \& Teuber, M. (1994a). Phylogenetic positioning of Acetobacter, Gluconobacter, Rhodopila and Acidiphilum species as a branch of acidophilic bacteria in the $\alpha$ subclass of Proteobacteria based on 16S rDNA sequences. Syst Appl Microbiol 17, 189-196.

Sievers, M., Ludwig, W. \& Teuber, M. (1994b). Revival of the species Acetobacter methanolicus (ex Uhlig et al., 1986) nom. rev. Syst Appl Microbiol 17, 352-354.

Sievers, M., Gaberthül, C., Boesch, C., Ludwig, W. \& Teuber, M. (1995). Phylogenetic position of Gluconobacter species as a coherent cluster separated from all Acetobacter species on the basis of $16 \mathrm{~S}$ rRNA sequences. FEMS Microbiol Lett 126, 123-126.

Sokollek, S. J. \& Hammes, W. P. (1997). Description of a starter culture preparation for vinegar fermentation. Syst Appl Microbiol 20, 481-491.

Sokollek, S. J., Hertel, C. \& Hammes, W. P. (1998a). Cultivation and preservation of vinegar bacteria. J Biotechnol 60, 195-206.

Sokollek, S. J., Hertel, C. \& Hammes, W. P. (1998b). Description of Acetobacter oboediens sp. nov. and Acetobacter pomorum sp. nov., two new species isolated from industrial vinegar fermentations. Int J Syst Bacteriol 48, 935-940.

Springer, N., Ludwig, W., Drozanski, V., Amann, R. \& Schleifer, K.-H. (1992). The phylogenetic status of Sarcobium lyticum, an 
obligate intracellular bacterial parasite of small amoebae. FEMS Microbiol Lett 96, 199-202.

Stackebrandt, E. \& Goebel, B. M. (1994). Taxonomic note: a place for DNA-DNA reassociation and 16S rRNA sequence analysis in the present species definition in bacteriology. Int $J$ Syst Bacteriol 44, 846-849.

Stolz, P., Böcker, G., Vogel, R. F. \& Hammes, W. P. (1993). Utilization of maltose and glucose by lactobacilli isolated from sourdough. FEMS Microbiol Lett 109, 237-242.

Yamada, Y. (2000). Transfer of Acetobacter oboediens Sokollek et al. 1998 and Acetobacter intermedius Boesch et al. 1998 to the genus Gluconacetobacter as Gluconacetobacter oboediens comb. nov. and Gluconacetobacter intermedius comb. nov. Int J Syst Evol Microbiol 50, 2225-2227.

Yamada, Y., Hoshino, K. \& Ishikawa, T. (1997). The phylogeny of acetic acid bacteria based on the partial sequences of $16 \mathrm{~S}$ rRNA: the elevation of the subgenus Gluconacetobacter to generic level. Biosci Biotechnol Biochem 61, 1244-1251.

Yamada, Y., Hoshino, K. \& Ishikawa, T. (1998). Gluconacetobacter corrig. gen. nov. In Validation of the Publication of New Names and New Combinations Previously Effectively Published Outside the IJSB, List no. 64. Int J Syst Bacteriol 48, 327-328. 